\title{
СКРИНИНГ БАКТЕРИЙ С АНТИБАКТЕРИАЛЬНОЙ АКТИВНОСТЬЮ ПРОТИВ ВACILLUS SUBTILIS И ESCHERICHIA COLI ШTAMMOB, НЕСУЩИХ ПЛАЗМИДЫ ОБЕСПЕЧИВАЮЩИЕ УСТОЙЧИВОСТЬ К ИЗВЕСТНЫМ АНТИБИОТИКАМ
}

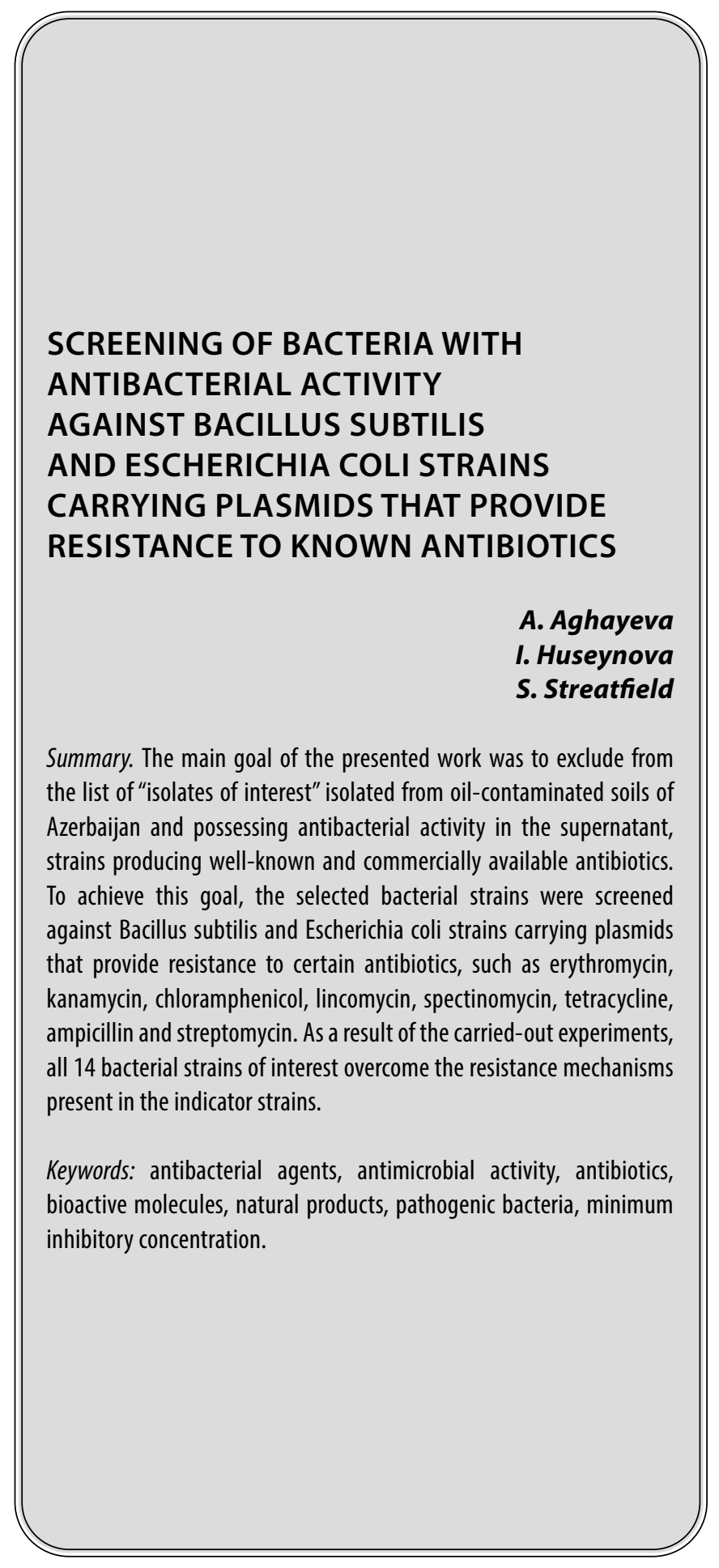

\begin{abstract}
Агаева Айтан Габиловна
С.н.с., Институт молекулярной биологии и биотехнологий НАН Азербайджана

aytanaghayeva@gmail.com

Гусейнова Ирада Мамедовна

Д.б.н, профессор, Институт молекулярной биологии и биотехнологий НАН Азербайджана i_guseinova@mail.ru

Стритфилд Дж. Стивен

Доктор философии по генетике, Директор, Отдел Биотехнологий Фраунхофер США, Центр Средней Атлантики, Ньюарк, США sstreatfield@fraunhofer.org

Аннотация. Основной целью представленной работы было исключение из списка «интересующих изолят», выделенных из нефтезагрязненных почв Азербайджана и обладающих антибактериальной активностью в супернатанте, штаммов, продуцирующих известные и коммерчески доступные антибиотики. Для реализации поставленной цели был осуществлен скрининг выбранных бактерий против Bacillus subtilis и Escherichia coli штаммов, несущих плазмиды, обеспечивающие устойчивость к определенным антибиотикам, таким как эритромицин, канамицин, хлорамфеникол, линкомицин, спектиномицин, тетрациклин, ампициллин и стрептомицин. В результате проведенных экспериментов, все 14 бактериальных штамма, представляющие интерес, превосходят механизмы устойчивости, присутствующие в индикаторных штаммах.
\end{abstract}

Ключевые слова: антибактериальные агенты, антимикробная активность, антибиотики, биоактивные молекулы, натуральные продукты, патогенные бактерии, минимальная ингибирующая концентрация. 


\section{Введение}

$\mathbf{M}$ икроорганизмы производят ряд полезных соединений - биоактивных натуральных продуктов, которые широко используются в различных отраслях промышленности и медицине (Kumar et al., 2017; Singh et al., 2017). С другой стороны, приблизительно 98\% видов микроорганизмов не идентифицированы по сей день и не подлежат культивированию в лабораторных условиях (Wade, 2002; Vitorino et al., 2018; Kellenberger, 2001), и это означает, что все применяемые в промышленности и медицине биомолекулы микробного происхождения продуцированы 2\% известных науке видов микроорганизмов.

Как известно, большинство применяемых в медицине антибиотиков были выделены непосредственно из живых организмов, то есть являются натуральными продуктами, или представляют собой модифицированные соединения, основные структуры которых получены от природы (Ali et al., 2018; Jones et al., 2017). Однако существуют некоторые сложности в обнаружении и разработки новых натуральных продуктов для терапевтических целей (Lewis, 2013). Одним из основных проблем в разработке новых лекарственных продуктов из натуральных продуктов является большая вероятность переоткрыть ранее обнаруженные биологически активные соединения (Hughes and Karlén, 2014). В большинстве случаев, на последних этапах разработки обнаруживается, что данная молекула была ранее идентифицирована. Таким образом, выявление известных соединений из экстрактов натурального продукта на ранних стадиях разработки способствует сохранению ресурсов и ускоряют процесс обнаружения новых лекарств (Jackson et al., 2018).

В 2014-2018 годах была создана коллекция бактерий, изолированных из нефтезагрязненных почв Азербайджана. Первичный скрининг и скрининг супернатанта на наличие в коллекции штаммов с антибактериальной активностью, выявил 14 штаммов, которые были внесены в список «интересующих изолят» (Агаева, 2020). Так как разработка лекарственных препаратов очень долгий и дорогостоящий процесс, и в большинстве случаев существует риск обнаружения ранее идентифицированных соединений, в процесс разработки важно включать стадии, необходимые для получения предварительной информации о строении и механизме активности выбранных соединений. Основной целью представленной работы было исключение из списка «интересующих изолят» штаммов, продуцирующих известные и коммерчески доступные антибиотики. Для реализации поставленной цели был осуществлен скрининг выбранных бактерий против Bacillus subtilis и Escherichia coli штаммов, несущих плазмиды, обе- спечивающие устойчивость к определенным антибиотикам.

\section{Материал и методы}

Объектами исследований служили 14 бактериальных штаммов, изолированных из нефтезагрязненных почв Азербайджана, которые обладали активностью в супернатанте против одного из четырех условно-патогенных штаммов, таких как Staphylococcus aureus ATCC29213, Enterococcus faecalis и двух Escherichia coli (эталонный (DC0) и мутант проницаемости наружной мембраны (DC2) (Richmond et al., 1976)) штаммов (Агаева, 2020). Так как на данном этапе исследований штаммы с антибактериальной активностью считались неизвестными, они могли продуцировать идентифицированное ранее биоактивное соединение. Для того, чтобы элиминировать штаммы с уже открытыми механизмами активности был осуществлен антибактериальный скрининг выбранных изолят против Bacillus subtilis и Escherichia coli штамм-индикаторов, несущих плазмиды обеспечивающие устойчивость к определенным антибиотикам. Изоляты с супернатантной активностью подвергали скринингу против шести штаммов Bacillus subtilis (пять штаммов, обладающих устойчивостью к известным антибиотикам, и одного контрольного штамма без какой-либо устойчивости к антибиотику) и четырех штаммов Escherichia coli (три штамма, обладающих устойчивостью к известным антибиотикам и одного контрольного штаммов).

Этот этап был включен для того, чтобы показать, что антимикробные молекулы, продуцируемые выбранными нами изолятами, не являются одним из ранее описанных коммерчески доступных антибиотиков. Штаммы Bacillus subtilis были получены из Bacillus Genetic Stock Center (BGSC), а штаммы Escherichia coli - во Фраунхоферском Центре Средней Атлантики, США. Идентификация всех вышеуказанных штаммов-индикаторов подтверждена путем секвенирования гена $16 \mathrm{~S}$ PPHK. Для подтверждения устойчивости штаммов-индикаторов к определенным антибиотикам, штаммы были выращены в чашках, содержащих определенную концентрацию соответствующих антибиотиков. В таблице 1 представлены штаммы Bacillus subtilis (грамположительные) и Escherichia coli (грамотрицательные) и соответствующая им устойчивость к антибиотикам.

Кроме того, присутствие гена устойчивости к определенным антибиотикам в плазмиде штаммов Bacillus и E. coli было подтверждено путем определения значений минимальной ингибирующей концентрации (МИК) против соответствующего антибиотика методом микроразведения в бульоне (Coyle et al., 2005) следуя рекомендациям Института клинических и лаборатор- 
Таблица 1. Штаммы Bacillus subtilis, Escherichia coli и соответствующая устойчивость к антибиотикам

\begin{tabular}{|l|l|}
\hline Штаммы & Устойчивость к антибиотикам \\
\hline Bacillus subtilis 1A1 & Контроль \\
\hline Bacillus subtilis 1A717 & Эритромицин \\
\hline Bacillus subtilis 1A718 & Канамицин \\
\hline Bacillus subtilis 1A754 & Хлорамфеникол \\
\hline Bacillus subtilis 1A771 & Линкомицин \\
\hline Bacillus subtilis 1A774 & Спектиномицин \\
\hline Escherichia coli XL1-blue & Контроль и Тетрациклин \\
\hline Escherichia coli pGreen & Канамицин \\
\hline Escherichia coli puc19 & Ампициллин \\
\hline Escherichia coli pPBM765 & Стрептомицин \\
\hline
\end{tabular}

ных стандартов (CLSI). Протестированная концентрация антибиотиков 384-0.75 мкг / мл. Для определения МИК, 100 мкл антибиотика добавляли в первую ячейку 96-ячеечного планшета и дважды разбавляли в TSB вдоль ряда. Затем в каждую ячейку добавляли 50 мкл штамма-индикатора до конечной концентрации $5 \times 10^{4}$ клеток на ячейку. В качестве положительного контроля (100\% рост индикатора) к 50 мкл среды добавляли 50 мкл индикаторного организма; отрицательным контролем (отсутствие индикатора) служила только питательная среда - 100 мкл. Планшеты инкубировали при $37{ }^{\circ} \mathrm{C}$ в течение ночи в открытом пакете (для удержания влаги внутри). После инкубации измеряли оптическую плотность при 650 нм с использованием аппарата Molecular Devices Spectra MaxPlus.

Для скрининга, 14 активных в супернатанте штаммы были инокулированы в 50 мл TSB (триптический соевый бульон) среды и культивировали в течение ночи при $32{ }^{\circ} \mathrm{C}$ и 180 об / мин. После 24-часовой инкубации культуральные супернатанты очищали путем центрифугирования при $10000 \mathrm{~g}$ в течение 15 минут при $4{ }^{\circ} \mathrm{C}$ и фильтровали через 0,22 мкм PES мембрану (мембрана из полиэфирсульфона). Все собранные супернатанты были анализированы против штамм-индикаторов, представленных в таблице 1, методом подавления роста, как описано Хокет с некоторыми модификациями (Hockett and Baltrus, 2017). Сущность метода сводится к тому, что 10 мкл собранных супернатант наносили на чашки Петри с агаром, конфлюирующим со штамм индикатором (Balouiri et al., 2016; Hockett and Baltrus, 2017). Чашки инкубировали при $37{ }^{\circ} \mathrm{C}$ в течение 20-24 часов. По истечении времени инкубации измеряли диаметр прозрачной зоны - зоны подавления роста (ЗПР) индикаторного штамма.

\section{Результаты \\ и обсужАение}

В 2014-2018 годах была создана бактериальная коллекция, состоящая из бактериальных штаммов, изолированных из нефтезагрязненных почв Азербайджана. Первичный скрининг и скрининг супернатанта на наличие в коллекции штаммов с антибактериальной активностью, выявил 14 штаммов, продуцирующих биоактивное соединение в супернатант (Агаева, 2020). Все эти 14 активных в супернатанте штаммов были выбраны для дальнейшей характеристики и внесены в список «интересующих изолят». На следующей стадии, для исключения из списка «интересующих изолят» штаммов, продуцирующих известные коммерчески доступные антибиотики, эти изолята были подвергнуты скринингу против шести штаммов Bacillus subtilis (пять штаммов, обладающих устойчивостью к известному антибиотику, и одного контрольного штамма без какой-либо устойчивости к антибиотикам) и четырех штаммов Escherichia coli (три штамма, обладающие устойчивостью к известному антибиотику и одного контрольного штамма). Если супернатант «интересующего изолята» ингибировал рост контрольного штамма и штамма, который устойчив к определенному антибиотику, это означало, что данный штамм, продуцировал соединение, отличное от антибиотика, против которого штамм-индикатор был устойчив. Однако, если супернатант «интересующего изолята» ингибировал рост контрольного штамма, и не оказывал никакого влияния на рост устойчивого к антибиотикам штаммов, то можно сделать вывод о том, что изолят, скорее всего, продуцировал соединение, аналогичное известному антибиотику; этот изолят можно исключить из списка «интересующих изолят». 
Таблица 2. Минимальная ингибирующая концентрация (мкг / мл) антибиотиков против штаммов

Bacillus и E. coli с генами устойчивости к антибиотикам в плазмиде.

\begin{tabular}{|c|c|c|c|c|c|c|c|c|c|c|}
\hline$\overbrace{\text { Антибиотики }}^{\text {Шта }}$ & $1 \mathrm{~A} 1$ & $1 \mathrm{~A} 717$ & 1 A754 & 1 A771 & 1 A774 & 1 A718 & $\begin{array}{l}\text { XL1- } \\
\text { Blue }\end{array}$ & pGreen & pPBM-765 & puc-19 \\
\hline Эритромицин & $<0.75$ & $>384$ & $<0.75$ & 1.5 & 0.75 & $<0.75$ & & & & \\
\hline Канамицин & 3 & 0.75 & 3 & 1.5 & 1.5 & $>384$ & 12 & $>384$ & 24 & 24 \\
\hline Хлорамфеникол & 1.5 & 3 & 24 & 6 & 6 & 3 & & & & \\
\hline Линкомицин & 24 & 96 & 24 & 48 & 24 & 24 & & & & \\
\hline Спектиномицин & 24 & 12 & 24 & 24 & $>384$ & 24 & & & & \\
\hline Тетрациклин & 3 & 3 & 3 & 3 & 3 & 3 & 192 & 96 & 96 & 96 \\
\hline Ампициллин & 6 & $<0.75$ & 1.5 & 6 & 2 & 12 & 24 & 1.5 & 6 & $>384$ \\
\hline Стрептомицин & & & & & & & 6 & 6 & $>384$ & 6 \\
\hline
\end{tabular}

Таблица 3. Скрининг «интересующих изолятов» против штаммов B. subtilis, несущих плазмиды, кодирующие устойчивость к известным антибиотикам. Знак «+» указывает на наличие активности

\begin{tabular}{|c|c|c|c|c|c|c|}
\hline Штаммы & 1А1 (Контроль) & 1 A717 & 1 A718 & 1 A754 & 1 A771 & 1 A774 \\
\hline \multicolumn{7}{|l|}{ AZ-130 } \\
\hline \multicolumn{7}{|l|}{ AZ-195 } \\
\hline AZ-279 & + & + & + & + & + & + \\
\hline \multicolumn{7}{|l|}{ AZ-289 } \\
\hline AZ-302 & + & + & + & + & + & + \\
\hline \multicolumn{7}{|l|}{ AZ-330 } \\
\hline AZ-380 & + & + & + & + & + & + \\
\hline$A Z-402$ & + & + & + & + & + & + \\
\hline \multicolumn{7}{|l|}{$A Z-410$} \\
\hline$A Z-411$ & + & + & + & + & + & + \\
\hline AZ-437 & + & + & + & + & + & + \\
\hline AZ-463 & + & + & + & + & + & + \\
\hline AZ-469 & + & + & + & + & + & + \\
\hline$A Z-477$ & + & + & + & + & + & + \\
\hline
\end{tabular}

По результатам выращивания штаммов-индикаторов в чашках, содержащих соответствующий антибиотик, выяснилось, что штаммы-индикаторы росли только в тех чашках, в которых содержался антибиотик, к которым они обладали устойчивостью.

Подтверждение того, что ген в плазмиде штаммов Bacillus и E. coli действительно обеспечивает устойчивость к определенным антибиотикам, было осуществлено путем определения значений минимальной ингибирующей концентрации (МИК) антибиотиков против штамм-индикаторов (Таблица 2). При сравнении полученных результатов с контрольным штаммом, выяснилось, что штамм 1 A717 обладает устойчивостью к эритромицину, 1А718 - к канамицину, 1 A754 - к хлорамфениколу, 1 A771 - к линкомицину, 1 A774 - к спектиномицину, XL1-Blue - к тетрациклину, рuс-19 - к ампициллину, pGreen - к канамицину, pРВM-765 - к стрептомицину.
Результаты скрининга «интересующих изолят» штаммов против Bacillus subtilis и Escherichia coli штаммов, несущих плазмиды обеспечивающие устойчивость к определенным антибиотикам, представлены в Таблице 3. Как видно из таблицы 3, супернатант штаммов AZ-279, AZ-302, AZ-380, AZ-402, AZ-411, AZ-437, AZ-463, AZ-469 и AZ-477 обладают активностью против контроля и всех устойчивых к антибиотикам штаммов Bacillus subtilis; антимикробные препараты, продуцируемые этими штаммами, обладают грамположительной активностью и, скорее всего, механизм их активности отличается от известных протестированных антибиотиков. Мы не обнаружили никакой активности против грамотрицательных штаммов.

Эксперименты, проведенные против устойчивых к антибиотикам штаммов, показывают, что все 14 изолята, представляющие интерес, превосходят механизмы устойчивости, присутствующие в индикаторных штаммах. 


\section{Зак^ючение}

Учитывая, что разработка лекарственных препаратов очень долгий и дорогостоящий процесс, и в большинстве случаев существует риск обнаружения ранее идентифицированных соединений, в процесс разработки целесообразно включать стадии, необходимые для получения предварительной информации о строении и механизме активности выбранных соединений. Элиминирование штаммов с уже известным механизмом активности позволит сэкономить финансы и время.
В данной статье мы проанализировали активные в супернатанте штаммы бактерий, изолированные из нефтезагрязненных почв Азербайджана, против Bacillus subtilis и Escherichia coli штаммов, несущих плазмиды, обеспечивающие устойчивость к определенным антибиотикам. Полученные результаты показывают, что все 14 штамма, представляющих интерес, превосходят механизмы устойчивости, присутствующие в индикаторных штаммах, и могут быть кандидатом на новое антимикробное соединение. Дальнейшая характеристика выбранных микроорганизмов будет включать их идентификацию путем секвенирования 16S rRNA гена.

\section{ЛИТЕРАТУРА}

1. Агаева А.Г. Создание бактериальной коллекции на основе штаммов, изолированных из почв Азербайджана и их скрининг на наличие новых антибактериальных биомолекул // Журнал Наук о Жизни и Биомедицины., 2019, т. 1 (74), № 2, с. 13-19.

2. Ali S.M., Siddiqui R. and Khan N.A. Antimicrobial discovery from natural and unusual sources // J Pharm Pharmacol., 2018, v.70(10), p.1287-1300.

3. Balouiri M., Sadiki M., Ibnsouda S.K. Methods for in vitro evaluating antimicrobial activity: A review // J. Pharm. Anal., 2016, v. 6(2), p.71-79.

4. Coyle M.B. et al. Manual of Antimicrobial Susceptibility Testing. American Society for Microbiology, 2005,

5. Hughes D. and Karlén A. Discovery and preclinical development of new antibiotics // Ups J Med Sci., 2014, v. 119(2), p.162-169.

6. Hockett K.L., Baltrus D.A. Use of the soft-agar overlay technique to screen for bacterially produced inhibitory compounds // J. Vis. Exp., 2017. 119:55064.

7. Jackson N., Czaplewski L. and Piddock L.J.V. Discovery and development of new antibacterial drugs: learning from experience.// J Antimicrob Chemother, 2018. v73, p.1452-1459

8. Jones M.B., Nierman W.C., Shan Y., Frank B.C., Spoering A., Ling L., Peoples A., Zullo A., Lewis K., Nelson K.E. Reducing the bottleneck in discovery of novel antibiotics // Microbial Ecology., 2017, v.73(3), p.658-667.

9. Kellenberger E. Exploring the unknown. The silent revolution of microbiology // EMBO reports., 2001. V.2(1), p.5-7.

10. Kumar A., Chordia N. Role of microbes in human health // Applied Microbiology: Open Access., 2017, v.3(2).

11. Lewis K. Platforms for antibiotic discovery // Nature Reviews | Drug Discovery., 2013. v.12, p.371-387.

12. Richmond M.H, Clark D.C, Wotton S. Indirect method for assessing the penetration of beta-lactamase-nonsusceptible penicillins and cephalosporins in Escherichia coli strains // Antimicrob Agents Chemother., 1976, v.10(2), p.215-218.

13. Singh R., Kumar M., Mittal A., Mehta P.K. Microbial metabolites in nutrition, healthcare and agriculture // 3 Biotech., 2017, v.7(1), p.15.

14. Vitorino L.C., Bessa L.A. Microbial diversity: The gap between the estimated and the known // Diversity., 2018, v.10(2), p.46.

15. Wade W. Unculturable bacteria — the uncharacterized organisms that cause oral infections // J.R. Soc. Med., 2002, v. 95(2), p.81-83.

(c) Агаева Айтан Габиловна ( aytanaghayeva@gmail.com ),

Гусейнова Ирада Мамедовна ( i_guseinova@mail.ru ), Гусейнова Ирада Мамедовна ( sstreatfield@fraunhofer.org ).

Журнал «Современная наука: актуальные проблемы теории и практики» 